\title{
PUBLIC SERVICE MOTIVATION OF STUDENTS: A COMPARATIVE ANALYSIS FROM UNIVERSITIES OF RUSSIA AND SOUTH AFRICA \\ Ivan Pivovarov $^{1}$, Hendri Kroukamp ${ }^{2}$, Victoria Nekrasova ${ }^{3}$
}

\begin{abstract}
A career choice in the public sector might seem strange as more financially lucrative careers beckon in the private sector. Similarities and differences in the motivation of choosing and staying in the public sector between students currently enrolled in undergraduate studies towards a career in the public sector (referring to all spheres of government) in Russia and the Republic of South Africa are analyzed in this article. Through this process new knowledge is generated for public personnel managers in recruitment drives, promoting current and new employment opportunities possibilities are enhanced and ideas are generated for tertiary institutions for the development of curriculum to ensure that public servants will be able to address, through the attainment of the necessary skills, the changing circumstances within which public servants operate in the public sector. Recommendations in respect of further research possibilities are also explored.
\end{abstract}

JEL Classification Numbers: H83, I23, J45, DOI: 10.12955/cbup.v7.1369

Keywords: Public service, motivation, higher education, Russia, South Africa

\section{Introduction}

A career choice in the public sector might seem strange as more financially lucrative careers beckon in the private sector. Similarities and differences in the motivation of choosing and staying in the public sector between students currently enrolled in undergraduate studies towards a career in the public sector (referring to all spheres of government) in Russia and the Republic of South Africa are analyzed in this article. Through this process new knowledge is generated for public personnel managers in recruitment drives, promoting current and new employment opportunities possibilities are enhanced and ideas are generated for tertiary institutions for the development of curriculum to ensure that public servants will be able to address, through the attainment of the necessary skills, the changing circumstances within which public servants operate in the public sector. Recommendations in respect of further research possibilities are also explored.

\section{Theoretical framework}

Public Service Motivation generally explains what motivates persons to start their careers within the governmental sector as opposed to the business sector. The theoretical background of Public Service Motivation was established in 1970s and early 1980s by such researchers as Buchanan (1975), Rainey (1982), Mosher (1982), and Perry \& Porter (1982); however, the definition was formally introduced by Perry and Wise (1990). The authors argued that PSM is usually affected by different political, institutional, and social factors. Further, Perry (1996) created criteria to evaluate public service motivation, which are related conceptually to six aspects: willingness to participate in public policy making, dedication to the public interest, civic obligation, social equity, self-sacrifice, and compassion. Perry elaborated Likert-type items for each aspect to make the PSM scale and probed his theory by means of confirmatory factor analysis (CFA).

Ever since, PSM has achieved international recognition from different academicians and researchers. Redman-Simmons (2007) tested how the concepts of "public service" reflect the traditional public service ethos among graduate students, and how this influenced their career decisions. The author examined the motivational factors already identified in the public administration literature, among other variables associated with career choice from related literatures. To achieve this, the existing public service motivations construct (Perry, 1996) and its scale was included in the analysis.

Perry's PSM conclusions and antecedent questions was also used by Clerkin, Paynter and Taylor (2008), who surveyed undergraduate students at North Carolina State University. Further, to study students' motivations toward the public service, the authors asked more questions with a focus on volunteering and donating choices. The authors discover that respondents with higher levels of PSM tend to engage in charitable activity. Such personal characteristics as household income, political preferences, gender, religiousness, family socialization, and high school volunteering experiences are also greatly associated with the choices respondents make about participating in charitable events.

\footnotetext{
${ }^{1}$ Russian Presidential Academy of National Economy and Public Administration, ivan_pivovarov_@mail.ru

${ }^{2}$ University of the Free State, kroukhj@ufs.ac.za

${ }^{3}$ Russian Presidential Academy of National Economy and Public Administration, menedjment@uriu.ranepa.ru
} 
The surveying of students' public service motivation was continued by Rose (2013), who analyzed the data from a survey conducted via the Internet, where 529 students from the USA participated. The author concludes that despite the lack of confidence in governmental bodies and the negative perceptions toward government work, the interest in government careers can be predicted by policy making dimensions. In contrast, a dedication to public interest, compassion, and self-sacrifice can clarify student interest in nonprofit sphere as well as teaching activity - both jobs students see as more directly helping and serving people. In contrast, Lee \& Choi (2016), who studied public service motivation in Korea, found that the most significant reason why students planned to get employed in the public sector was job security.

Thus, despite few publications devoted to students' public service motivation, the reasons why university students make their choices towards a career of public servant are still understudied. The primary goal of the present research is to shed a light upon this less studied aspect, in particular by means of a comparable analysis of students' public service motivation in two different universities in Russia and South Africa.

\section{Methodology}

Within the scope of the present study, the authors examine the factors motivating students towards a career in public administration, which have already been identified in the public administration literature in Russia (Choban 2013). For this purpose, a questionnaire was distributed among undergraduate students in two universities. The first one was South Russia Institute of Management of the Russian Presidential Academy of National Economy and Public Administration (Russia) while the second one was the University of Free State (South Africa). The responses were collected in August 2018 and analyzed.

Overall 97 students participated in the survey, in particular, 69 from South Africa and 28 from Russia. The South African students studied at the second year of the Public Administration bachelor program while the Russian students studied at the third year.

The questionnaire consisted of 6 questions and they are as follows:

- In your opinion, is it a prestigious job to be a public servant?

- Are you going to become a public servant after you graduate from university?

- What are the main reasons not to become a public servant (or even if you plan to become one what obstacles can influence your decision?)

- What attracts you the most in the public servant profession?

- What advantages can a job in the business sector provide you that a job in the public sector cannot?

- Would you agree to change your job to a less paid one (30\%) in case you find a new job more interesting and exciting?

Questions 1, 2 and 6 presume one answer, questions 3 and 4 are multiple-choice questions, whilst question 5 is open-ended and asks a participant to express his or her opinion in a few words.

\section{Results}

According to the results of the survey at least half of the students being questioned in South Africa and Russia consider a job in public service prestigious (59.4\% and 55.2\% respectively). The other half of the participants in Russia (41.4\%) also considers it prestigious and choose the answer "more likely yes than no". In contrast, almost every forth participant from South Africa states that the job of a public servant is not prestigious for him/her (if to summarize answers "no" + "more likely no than yes" $17.4 \%$ and $7.2 \%$ respectively). It is also worth paying attention to the fact that in Russia only $3.5 \%$ of the respondents stated "no" and none of them expressed "more likely no than yes". The responses are illustrated in Figure 1.

The results of the responses to Question 2 are even more surprising. In South Africa $62.3 \%$ of the participants are going to become public servants after graduating from university. The reliability of this statement is precisely proved by the responses to Question 1. If we compare answers of "yes" to Question 1 (59.4\%) and Question 2, the results differ slightly.

At the same time in Russia only $17.2 \%$ of the respondents are going to start a career in public service in the future (Figure 2). This finding greatly contradicts to responses to Question 1 where $55.2 \%$ of the 
participants expressed their positive attitude to a career in public administration, defining this job as prestigious. The contradiction is that students in Russia find a job of public servant prestigious but do not generally plan to build a career in this sphere. This is one of the main results of the survey. The responses to Question 3 shed light on the reasons for this phenomenon.

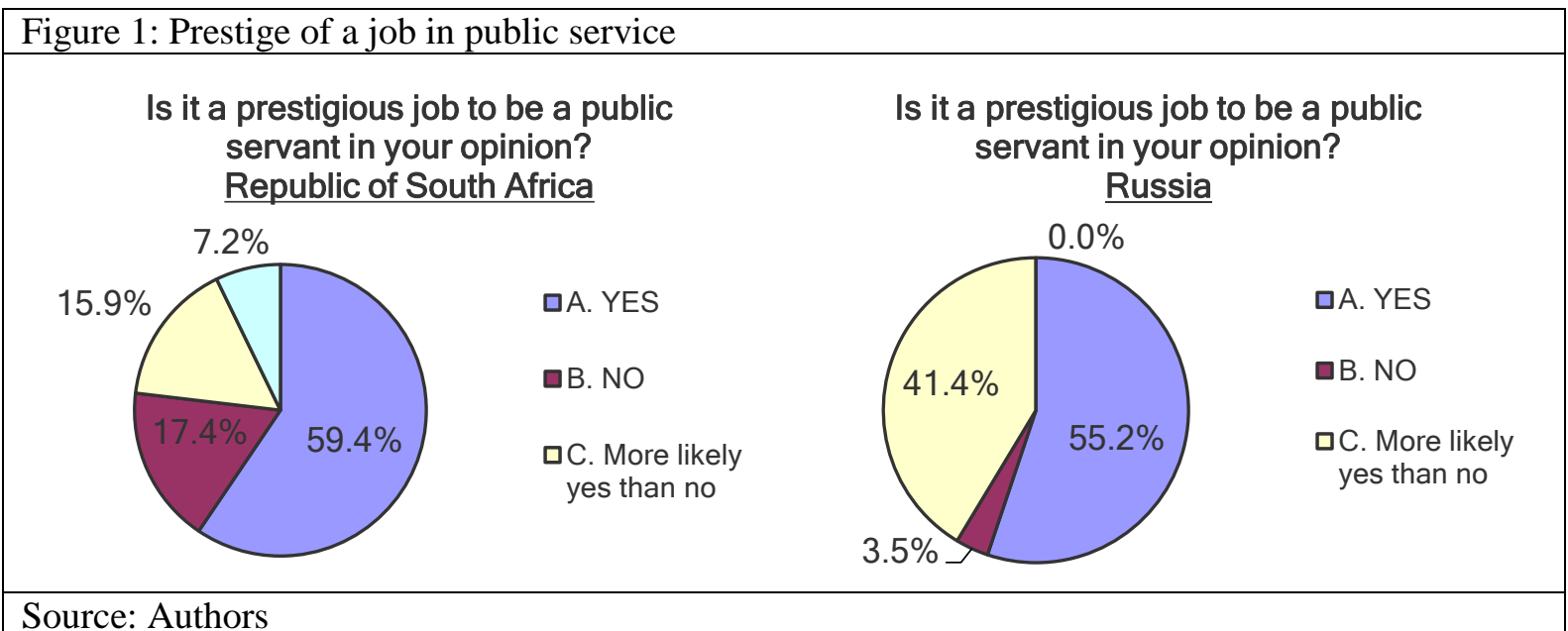

\begin{tabular}{|l} 
Figure 2: Willingness to become public servant \\
$\begin{array}{c}\text { Are you going to become a public servant after } \\
\text { you graduate from university? } \\
\text { Republic of South Africa }\end{array}$
\end{tabular}

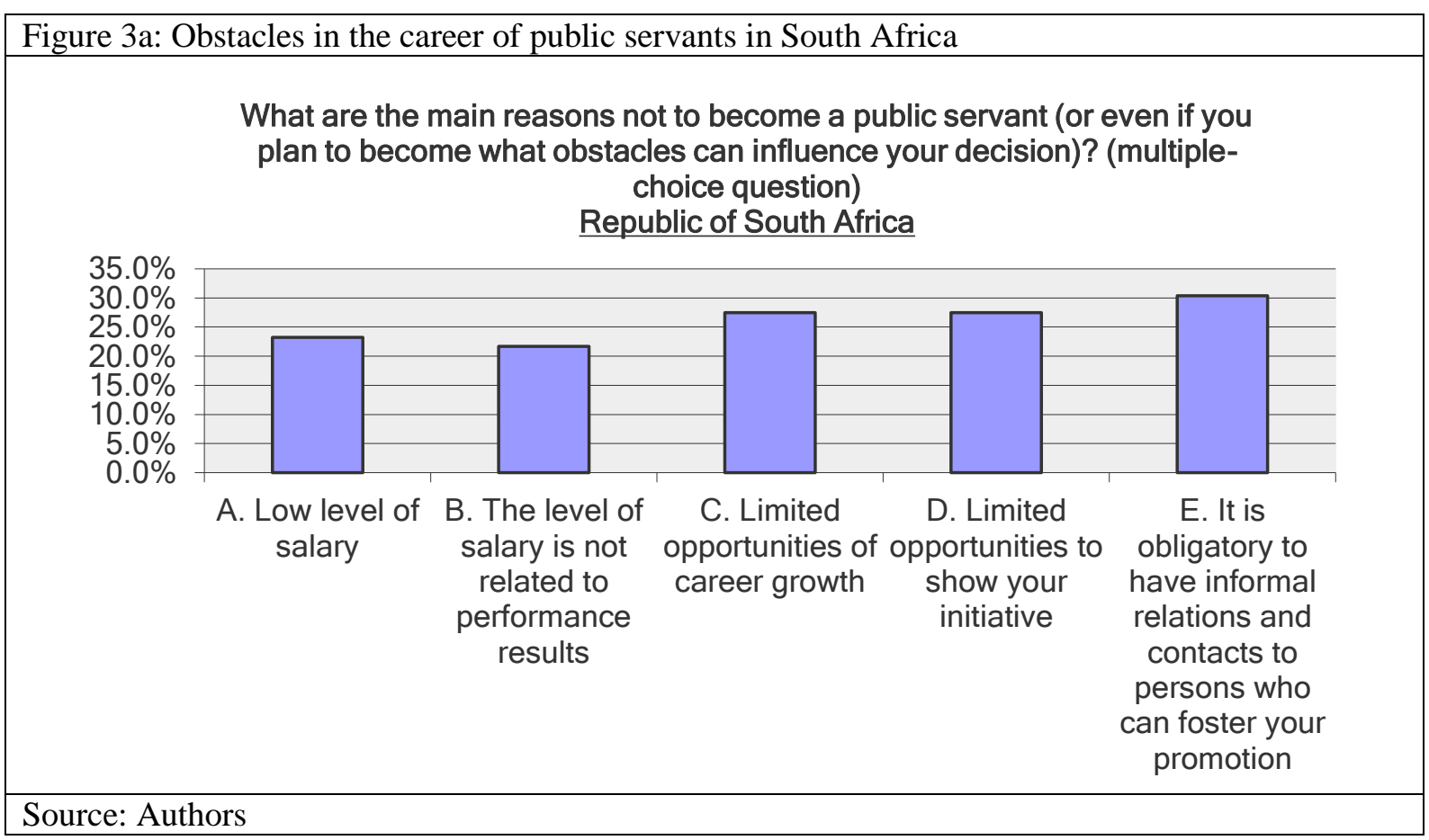


The explanation for the contradiction mentioned above is that the students in Russia are not attracted by a career in public administration due to the low level of salaries (51.7\%) and the need to have informal relations and contacts to persons who can foster the promotion (62.1\%) At the same time the results from South Africa are more evenly distributed, however, the main reason for not becoming a public servant in the future is still the same. According to the point of view of $30.4 \%$ of participants in South Africa it is obligatory to have informal relations and contacts for getting a career promotion in public administration. The responses to Question 3 are illustrated in Figure $3 \mathrm{a}$ and $3 \mathrm{~b}$.
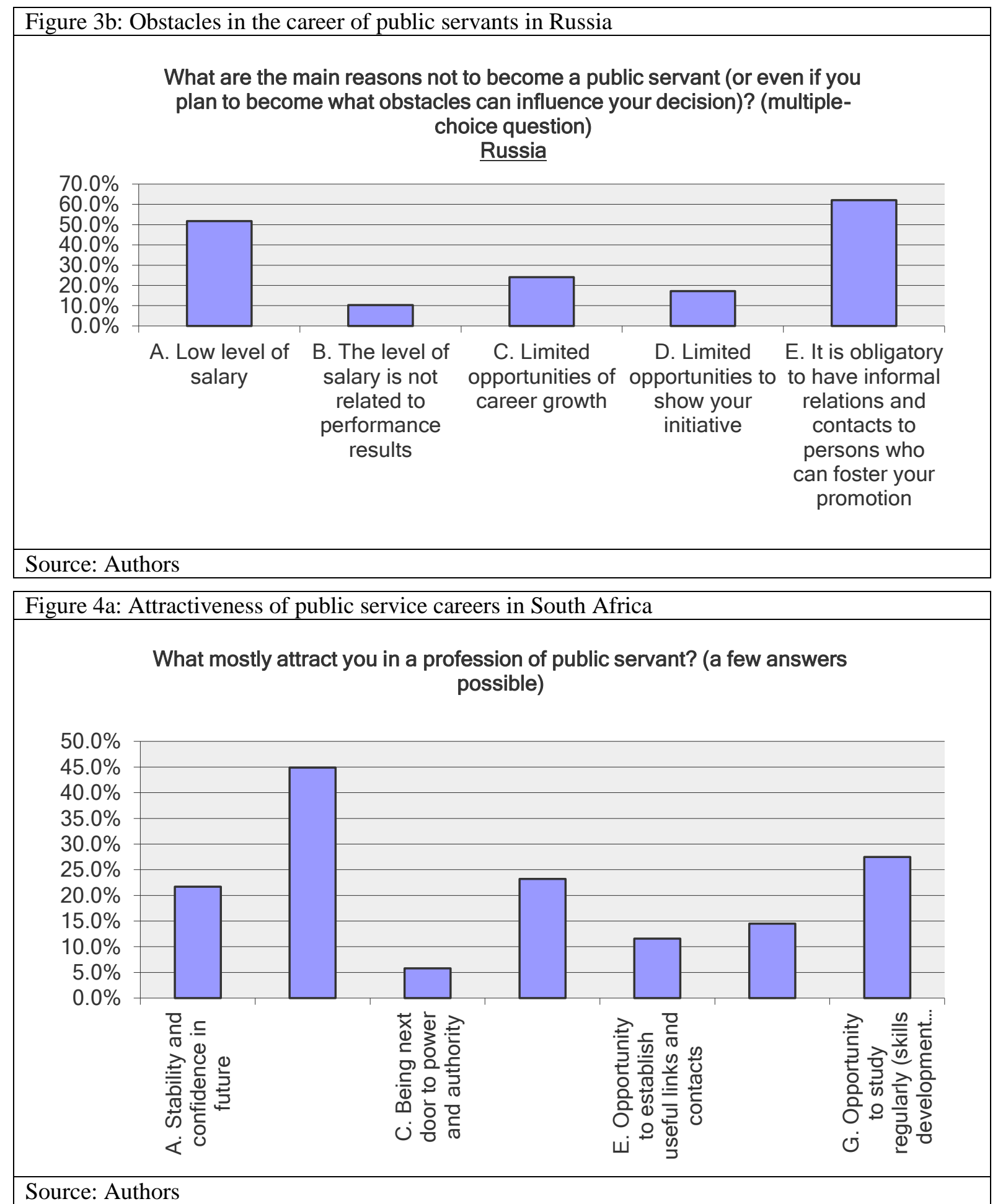

The responses to Question 4 explain the factors that attract student to public service. As it can be seen in Figure 4a and 4b, these factors significantly differ: South African students are mostly attracted by the opportunity to participate in events that have great social importance (44.9\%), while the students in 
Russia perceive social guarantees as the main advantage (69.0\%), as well as the opportunity to establish useful links and contacts $(41.4 \%)$. From the other side, the other types of responses (stability and confidence in future), in both countries are mostly evenly distributed (22.7\%-17.2\% in Russia, $27.5 \%-21.7 \%$ in South Africa).

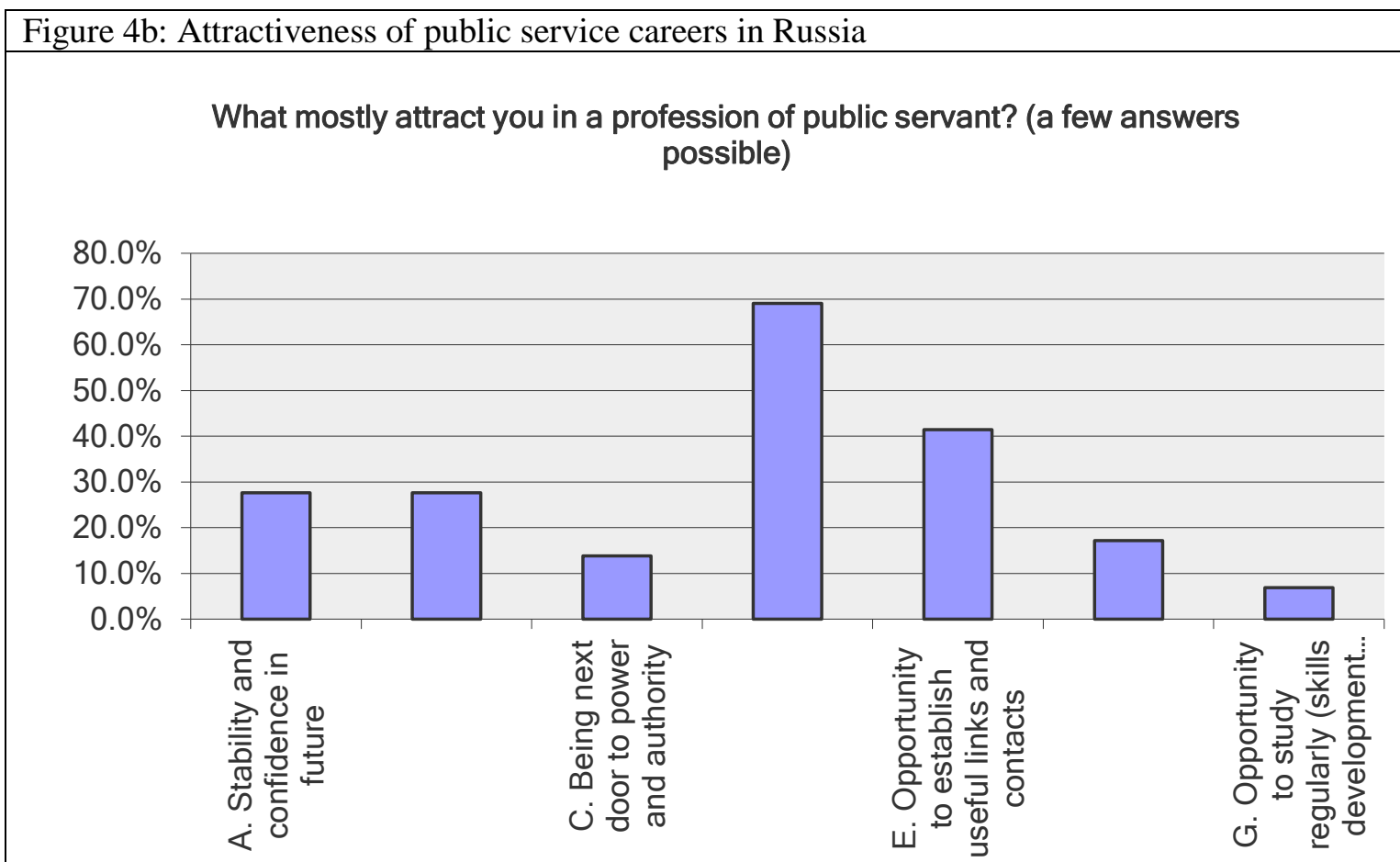

\section{Source: Authors}

Developing further the idea of attractiveness of the public service to students' advantage that a job in the business sector can give in comparison with a job in the public sector were analyzed (Tables 1a and $1 \mathrm{~b}$ ). In both countries higher salary, promotion opportunities and self-actualization are the main drivers that determine career choice in favor of the business sector.

From the other side, the students from South Africa specified a few important factors that were not mentioned by the Russian students. These are as follows: lower level of corruption in the business sector, opportunity to establish new professional links, as well as learning and skills development.

Another finding is that Russian students consider that the public sector has a large potential for establishing useful links and contacts, while South African students consider that a job in the business sector will give them more useful links and contacts in comparison with a public sector. This finding absolutely proves the results from the Question 4.

\begin{tabular}{|l|}
\hline Table 1a: Advantages of business sector job over public sector job (South Africa) \\
\hline The opportunity to make it more effective and efficient \\
\hline Career growth \\
\hline More networks \\
\hline An opportunity to grow my career \\
\hline Promotion \\
\hline You will have the opportunity to do what you passionate about \\
\hline It gives you the opportunity to be self employed \\
\hline In a business sector I would have an opportunity to manage myself and in a public sector I can only manage people \\
\hline If it is a family company, a family member can get a top position without experience and necessary education \\
\hline There is usually control measures to eliminate corruption in the private sector than in public sector so work ethic \\
\hline Medical and social insurance, pension support after retirement \\
\hline Medical benefits, job security \\
\hline Opportunity to establish useful links and contacts. Professional self-realization \\
\hline Better benefits, more pay, post based on merit, less fraudulent behaviour \\
\hline Growth potential in terms of career \\
\hline Learn more things in order to gain experience \\
\hline More security in my job \\
\hline I dont think there is a job that the business sector can offer that the public sector cannot offer \\
\hline Proper training and development \\
\hline
\end{tabular}




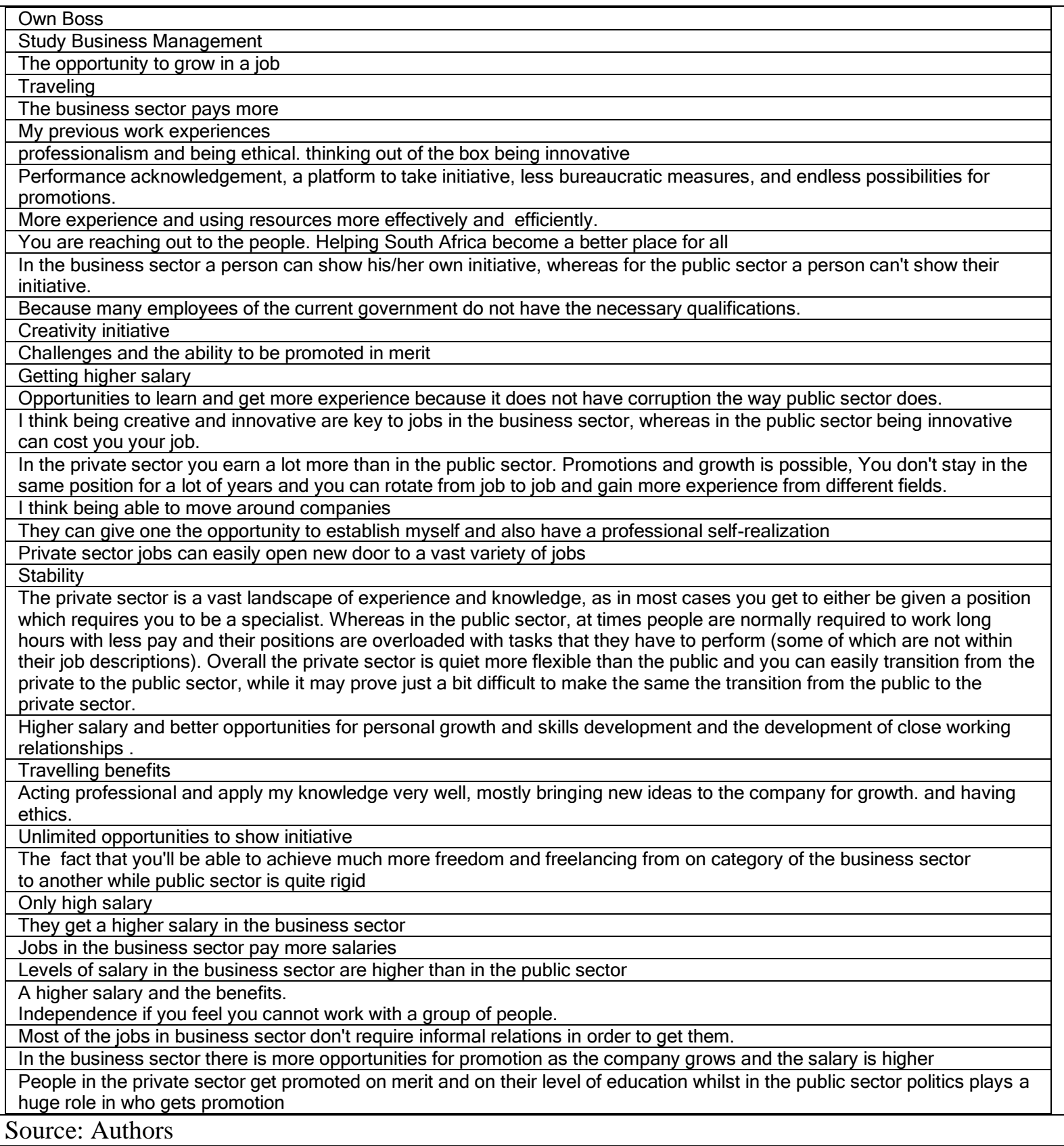

Table 1b: Advantages of business sector job over public sector job (Russia)

\begin{tabular}{l|}
\hline Higher opportunities for self-actualization, to show the initiative, to get a promotion in a shorter time period \\
\hline High level of salary \\
Salary is high \\
\hline Independence and freedom \\
\hline Career growth \\
\hline Fast career growth, higher income, opportunity to start your own business \\
\hline Diversity of tasks, encouragement of initiative \\
\hline Higher salary \\
\hline Higher salary \\
\hline Higher salary \\
\hline Higher salary \\
\hline Higerything \\
\hline Interesting job, income is higher, career promotion \\
\hline More creative approach to a job \\
\hline Hig easier to get employed \\
\hline Self-actualization \\
\hline Salary, faster career promotion and development, more convenient working schedule \\
\hline
\end{tabular}




\begin{tabular}{|l|}
\hline Career growth, higher level of salary \\
\hline To show yourself, a desire for a job \\
\hline Self-actualization, initiative \\
\hline Higher salary \\
\hline Higher salary \\
\hline Higher salary \\
\hline Source: Authors \\
\hline
\end{tabular}

Finally, it was explored whether students would agree to change their job to a less paid one (30\%) in case it is more interesting and exciting (Figure 5). The results demonstrate a high level (not absolute) of similarity of students' attitudes towards changing their job for a more prestigious, but less payed one. $38 \%$ of respondents in Russia would change their job, while $62 \%$ would not. In South Africa the results are $30.4 \%$ and $69.6 \%$ respectively.

The difference between the countries' results is that in Russia people stated their wish to change their job more definitely (24.1\% "yes" and only $13.8 \%$ "more likely yes"), while in South Africa the percentage is almost equal ( $14.5 \%$ and $15.9 \%$ respectively).

On the opposite side, in Russia the percentage of students who responded negatively is equal (31\% "no" and 31\% "more likely no"), while in South Africa the majority of students being questioned specified no $(47.8 \%)$.

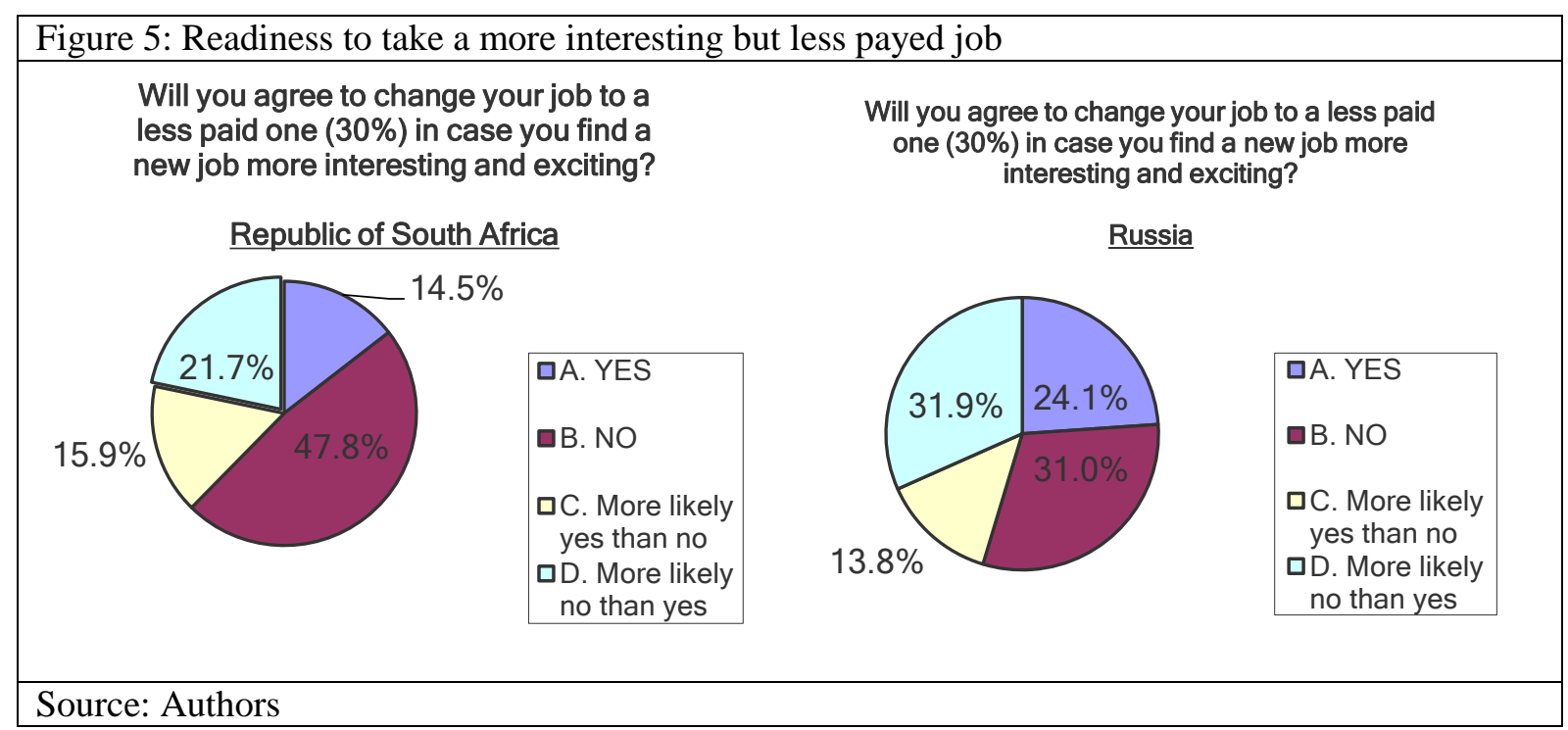

\section{Conclusions}

The results of the survey show us that at least half of the students being questioned in South Africa and Russia consider a job of public servant prestigious (59.4\% and $55.2 \%$ respectively). In turn, in South Africa $62.3 \%$ of participants are going to become public servants after graduation from university. At the same time in Russia only $17.2 \%$ of respondents are going to follow that route.

In fact, students in Russia, being questioned, find a job of public servant prestigious but do not generally plan to build a career in this sphere due to the low level of salaries and possible obstacles of career promotion in the public sector. On the basis of this finding the suggestion might be made that the young generation in Russia has overvalued expectations regarding starting levels of salary after university graduation as well as a desire to reach high career results in a short time period. The reliability of this suggestion and, in particular, regarding Russian young generation, is worth considering in future research.

The main reason for not becoming a public servant in the future in South Africa is the same as in Russia.

The factors that attract students to the public service significantly differ: South African students are mostly attracted by the opportunity to participate in events that have a great social importance, while the students in Russia perceive social guarantees as the main advantage, as well as the opportunity to establish useful links and contacts. 
The percentage of students in South Africa who are attracted by the opportunity to take part in events that have a great social importance, is high due to socio-economic backlogs as well as the social environment from which the majority of the students come from. Participation in events is seen as an opportunity to break free from these adverse circumstances to get access to the 'better life', so to speak. Students see Public Administration and Management as part of a government with flashy social opportunities such as stylish clothes, luxurious cars etc. To therefore show that a person has money might be interpreted as that he or she 'has arrived'. Social status is therefore very important and can be the reason for being attracted to the field of public administration. Obviously, students often misunderstand definitions of "public administration" and "public policy" and that is the main reason why they perceive public administration as the participation in big social events.

Explaining the Russian results it is worth saying that indeed a job in a public sector can provide a higher level of social guarantees and job security - public servants do not have such high wages as people from the business sector, however, public servants often obtain extra payments quarterly and the end of the year. Moreover, the level of corporate social responsibility of some part of companies in Russia in still not high and cases when an employer violates the rights of employees are still common in the business sector. The opportunity to establish useful links and contacts, perceived as a necessary part of a public administration career in Russia, greatly illustrates the specifics of the Russian mentality, traditions and attitude of people towards solving their day-to-day problems. Professional relations in Russia (both in public and business sector) are mostly built on personal trust (for example, employees recruitment based on friends or relatives' recommendations).

The main factors, explaining why a business career might be more attractive than a public administration career, are higher salary, better promotion opportunities and self-actualization. These factors are more or less applicable for both groups of students being questioned. At the same time students from South Africa see a lower level of corruption in the business sector, the opportunity to establish new professional links, as well as learning and skills development as the main business career advantages, while the Russian students do not specify them. The assumption may be made that Russian students do not perceive the business sector as a less corrupted sphere in comparison with public administration. That might be another question for further consideration.

Finally, the percentage of students ready to change their job to a less paid one is very similar in both students groups being researched and demonstrates the level of distribution of their material and nonmaterial motivation.

\section{References}

Bright, L. (2016). Public service motivation and socialization in graduate education. Teaching Public Administration, 34 (3), 284-306.

Buchanan, B. (1975). Red-Tape and the Service Ethic Some Unexpected Differences Between Public and Private Managers. Administration \& Society, 6 (4), 423-444.

Clerkin, R., Paynter, S., Taylor, J. (2009). Public Service Motivation in Undergraduate Giving and: Volunteering Decisions. The American Review of Public Administration, 39 (6), 675-698.

Lee, G., Choi, D. (2016). Does Public Service Motivation Influence the College Students'.Intention to Work in the Public Sector? Evidence From Korea. Review of Public Personnel Administration, 36 (2), 145-163.

Mosher, F. (1982). Democracy and the Public Service. Oxford: Oxford University Press.

Perry, J., Porter, L. (1982). Factors Affecting the Context for Motivation in Public Organizations. The Academy of Management Review, 7 (1), 89-98.

Perry, J., Wise, L. (1990). The motivational bases of public service. Public Administration Review, 50 (3), 367-373.

Rainey, H. (1982). Reward Preferences among Public and Private Managers: In Search of the Service Ethic. The American Review of Public Administration, 16 (4), 288-302.

Redman-Simmons, L. (2007). Graduate Students Attraction to Government Public Service Professions. A dissertation submitted to the Graduate School-Newark Rutgers, The State University of New Jersey.

Rose, R. (2013). Preferences for Careers in Public Work: Examining the Government-Nonprofit Divide Among Undergraduates Through Public Service Motivation. The American Review of Public Administration, 43 (4), $416-437$. 